\title{
An Evaluation of Bera Lake (Malaysia) Sediment Contamination Using Sediment Quality Guidelines
}

\author{
Mohammadreza Gharibreza, ${ }^{1,2}$ Muhammad Aqeel Ashraf, ${ }^{1,3}$ \\ Ismail Yusoff, ${ }^{3}$ and John Kuna Raj ${ }^{3}$ \\ ${ }^{1}$ Department of Geology, University of Malaya, 50603 Kuala Lumpur, Malaysia \\ ${ }^{2}$ Soil Conservation and Watershed Management Research Institute, P.O. Box 13445-1136, Tehran, Iran \\ ${ }^{3}$ Department of Chemistry, University of Malaya, 50603 Kuala Lumpur, Malaysia
}

Correspondence should be addressed to Muhammad Aqeel Ashraf; chemaqeel@gmail.com

Received 21 August 2012; Revised 25 December 2012; Accepted 4 January 2013

Academic Editor: Javier Hernandez-Borges

Copyright (C) 2013 Mohammadreza Gharibreza et al. This is an open access article distributed under the Creative Commons Attribution License, which permits unrestricted use, distribution, and reproduction in any medium, provided the original work is properly cited.

\begin{abstract}
Bera Lake is known as the first RAMSAR site and is the largest natural lake in Malaysia. Sediment quality guidelines (SQGs) and Geoaccumulation index were used to evaluate Bera Lake sediment contamination. Five undisturbed cores were collected from Bera Lake sediment. Major and trace levels of elements were determined for 132 subsamples using an inductively coupled plasma mass spectrometry (ICP-MS). The results marked two major groups of metallic elements bonded to the terrestrial and organic-rich sediments. Terrestrial sediments were strongly associated with accumulation of $\mathrm{Li}, \mathrm{Al}, \mathrm{Pb}, \mathrm{Cu}, \mathrm{Cr}, \mathrm{Na}, \mathrm{Mg}$, $\mathrm{Sr}$, and $\mathrm{K}$ during main fluxes of metals. However, a strong positive correlation was obtained between $\mathrm{Fe}, \mathrm{Mn}, \mathrm{As}, \mathrm{Zn}, \mathrm{Cu}, \mathrm{Ni}, \mathrm{Ca}$, and $\mathrm{Cd}$ elements and TOC and TN. The $\mathrm{Mn} / \mathrm{Fe}$ ratio revealed a long-term redox and acidic condition at Bera Lake. Geoaccumulation index for all individual metals has classified Bera Lake sediment as low to moderately polluted. However, elemental values when compared with thresholds limits of SQG indicated that Bera Lake sediments were contaminated by arsenic and iron. Results prove that deforestation during the five phases of land developments since 1972 has significantly contributed to the existence of metals fluxes into the area.
\end{abstract}

\section{Introduction}

Rapid industrial and agricultural developments during the past few decades have changed the sediment and water quality of the natural lakes around the world. Metallic elements, acidification, pesticides, oil, and eutrophication are the key areas of concern for the researchers for evaluating impact assessment in the ecosystem [1]. Studies were done and new investigations were introduced to protect aquatic life, the general environment, and human health [2-7]. In the recently adopted method for impact assessment, metallic elements values can be compared with the threshold limits of standard values which have also been proved by various environmental protection agencies [8-10].

Malaysian scientists [11, 12] have also conducted studies to assess the level of contamination in sediment and soil using SQG. An integrated ecosystem research project on Bera Lake was conducted by a joint Malaysian-Japanese team during the period 1970-1974. However, deforestation since 1972 during the five phases of land development plan by FELDA (Federal Land Development Authority) for oil palm and rubber plantations in the Bera Lake catchment has disturbed the ecosystem balance in the area [13]. The literature review highlighted a gap that Bear lake sediment has never been assessed using quality guidelines. Current issues at Bera Lake have attracted the attention of the author for an evaluation of Bera Lake sediment contamination. The main objectives of the present study are to recognize pollution status and determination of natural and anthropogenic sources of metallic elements fluxes at Bera Lake sediment. The results of analysis have been verified by sediment quality indices, Geoaccumulation index (Igeo), and statistical analysis.

1.1. Study Area. Bera Lake, a well-known open water natural lake in Peninsular Malaysia, is situated in the east-central part of Pahang State, a sanctuary for more than 200 bird 


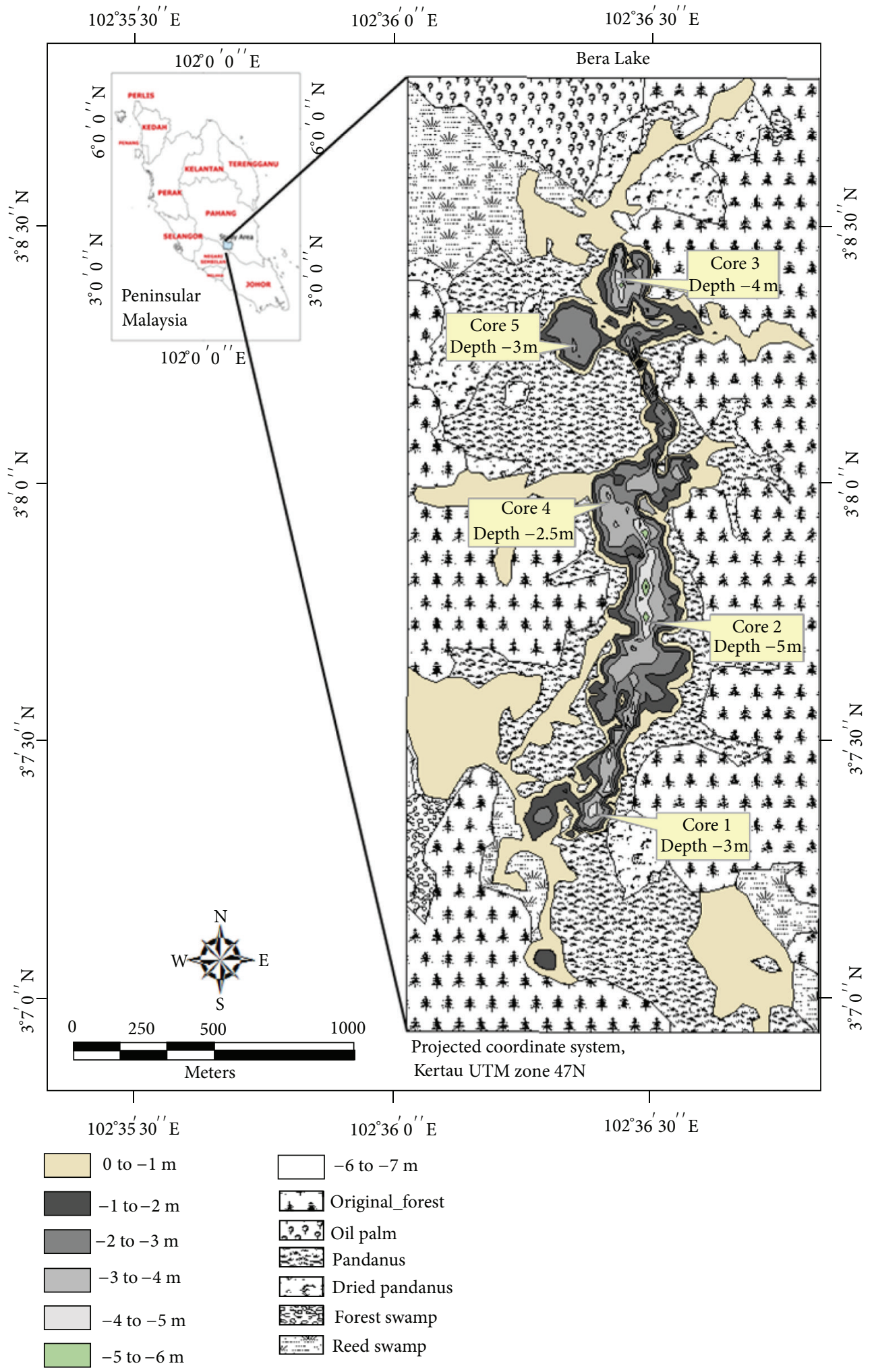

FIGURE 1: Bera Lake morphology and core sampling positions.

species, 50 mammal species, and 94 fish species [14]. The open water area of Bera Lake is calculated to be 112 ha which is located at the northernmost part of the catchment. The maximum depth of lake is measured to be $7 \mathrm{~m}$ while the average depth is $2.66 \mathrm{~m}$ (Figure 1). The total drainage area obtained is $593.10 \mathrm{~km}^{2}$ of which $340 \mathrm{~km}^{2}$ are covered by rubber and palm oil plantations while the rest is wetland, pristine, and lowland rain forests.

Bera Lake is located about $110 \mathrm{~km}$ far from the sea at an elevation of $25-30 \mathrm{~m}$. The surrounding hills are up to $140 \mathrm{~m}$ 
above sea level which are placed between the eastern and western mountain ranges. Stratigraphic sequence of study area is comprised of Permian massive mudstone, thick to massive tuffaceous sandstone, siltstone of Bera Formation, unconformably overlain by basal conglomerate and Triassic carbonaceous shale, siltstone, and rhyolitic tuff of Semantan Formation. Quaternary conglomerate or Kerum Formation has overlain the Semantan Formation by post-Triassic conglomerate, pebbly sandstone, and sandstone [15]. Organicrich and peat deposits have accumulated in the wetlands and open waters since 4,500-5,500 years ago [16, 17]. Based on some field observations, the formations bedding showed that Bera Lake catchment is located at the right flank of a wide syncline, trending NW-SE and layers inclined $45-60^{\circ} \mathrm{SE}$. According to the field observations and laboratory analyses, the soils of the Bera Lake catchment were recognized to be Ferralsols which are soils with brownish yellow, yellow, and red colours having developed on the Triassic and postTriassic continental sedimentary rocks. These Ferralsols have maximum and average thickness of 1 and $0.2 \mathrm{~m}$, respectively.

\section{Experimental}

2.1. Sampling. A total of five sediment core samples (three from the central part while two from semiclosed areas) were collected from the Bera Lake by newly developed innovative core sampler (Figure 1). The novelty of corer has been acknowledged and approved by Centre of Innovation and Commercialization of Malaysia vide patent no. PI2011003971. Core sampler was designed for $2 \mathrm{~m}$ undisturbed core sampling with high recovery rate and minimum sediment column compaction.

2.2. Sample Preparation and Analytical Methods. Core samples were sealed and stored vertically to prevent them from being mixed while they were transported to the laboratory. The cores were preserved in a freezer at the temperature of $4^{\circ} \mathrm{C}$, and then the frozen cores were taken out by an extruder whose diameter was lower than the interior liner diameter. The main idea behind the core freezing was to minimise the sediment column compaction during slicing. The cores were sliced at $2 \pm 0.2 \mathrm{~cm}$ intervals using plastic saw. A total of 132 samples were dried at $80-110^{\circ} \mathrm{C}$ and were ground for further analysis.

Digestion was performed by using microwave assisted acid digestion method 3052 [18]. Digested samples were analysed by inductively coupled plasma mass spectrometry (ICP-MS) Model Agilent Technologies 7500 Series. Sediment data in this study are reported on a dry weight $\mathrm{mg} \mathrm{kg}^{-1}$ basis.

Grain size distribution was analysed using the Master Seizer MALVERN model after a sample separation procedure. Grain size distribution diagrams, texture, and calculation of the statistical parameters were achieved by GRADISTAT, Version 6.0 [19]. The grain size analysis was performed to find a correlation between the contamination values and the special grain size groups. The stratigraphic description of sediment layers was achieved using grain size data and other sediment characters (Figure 2).
A total of 65 samples of Core 5 and Core 6 with a mass of $1-1.5 \mathrm{~g}$ were weighed and mixed with $1-2 \mathrm{~mL}$ of $\mathrm{HCl} 1 \mathrm{M}$ to remove inorganic carbons, and were dried about $10 \mathrm{~h}$ at $100-105^{\circ} \mathrm{C}$ to remove the $\mathrm{HCl}$. Then, $0.5-2 \mathrm{mg}$ samples were weighed and analyzed for Total Carbon (TC) and Total Nitrogen (TN) using PerkinElmer 2400 Series II CHNS/O Elemental Analyzer.

2.3. Quality Control. The analytical data quality was guaranteed through accomplishment of laboratory quality assurance and quality control methods, including the use of standard operating procedures, calibration with standards, analysis of reagent blanks, recovery of samples, and analysis of replicates. All sediment analyses were performed by the qualityaccredited laboratory of Geology, University of Malaya for the analyses of the sediment profiles, which were carried out at the Hydrogeo laboratory. Intra- and interlaboratory quality assurance and control (QA/QC) formed an integral part of the analysis schemes, for example, by regular validation with reference sediment samples, the use of control charts and of replicates [20].

Freshwater lake sediment standard reference material (SRM No. 4354) was used for the quality control test and quantitative analysis. Six replicate samples, each with a mass of $0.25 \mathrm{~g}$, were weighed, digested, and analysed by ICP-MS in a similar manner as the sediment samples. The blank and standard solutions were prepared for metallic elements in the order of $1,2,3,10,20$, and $50 \mathrm{ppm}$. The percentage recoveries of the metallic elements in the samples ranged from $81.7 \%$ (Ca) to $110 \%(\mathrm{Mg})$. Results of the repeated and reference samples were found in an acceptable limit range (75-125\%) for all analyzed metals and metalloids (Table 1).

An organic analytical standard (Acetanilide-C6H5NH) was used for quality control test and quantitative analysis. The quality control procedure was performed using Acetanilide standard sample as conditioner. Five blank-tin aluminium samples were tested. The calibration continued when positive results of $\mathrm{C}<50, \mathrm{H}: 100 \sim 200$, and $\mathrm{N}<16$ were obtained. Then, three replicates Acetanilide samples, each with a mass of $0.5-2 \mathrm{mg}$, were weighed and analysed by Perkin Elmer 2400 Series II CHNS/O Elemental Analyzer. The calibration factors for carbon, hydrogen, and nitrogen were, respectively, $71.09 \pm 0.3,6.71 \pm 0.3$, and $10.36 \pm 0.3 \%$, according to the instrumental instruction. The organic analytical standard (Acetanilide) was run for every four samples. CHN analysis was continued when the Acetanilide samples were gained in the range of calibration factors.

\subsection{Comparison of Metallic Elements Concentration with} Standard Levels. Sediment quality guidelines were recognized [22] as perfect thresholds to reveal adverse effects of metallic elements in sediments for aquatic life and human health. This study showed that sediment quality indices can clearly assess the overall pollution status at Bera Lake sediments. SQGs have been described in details for their abilities in detection of the pollution issues.

The lowest effect level (LEL) is a measure of contamination that has no effect on most of the sediment-dwelling 


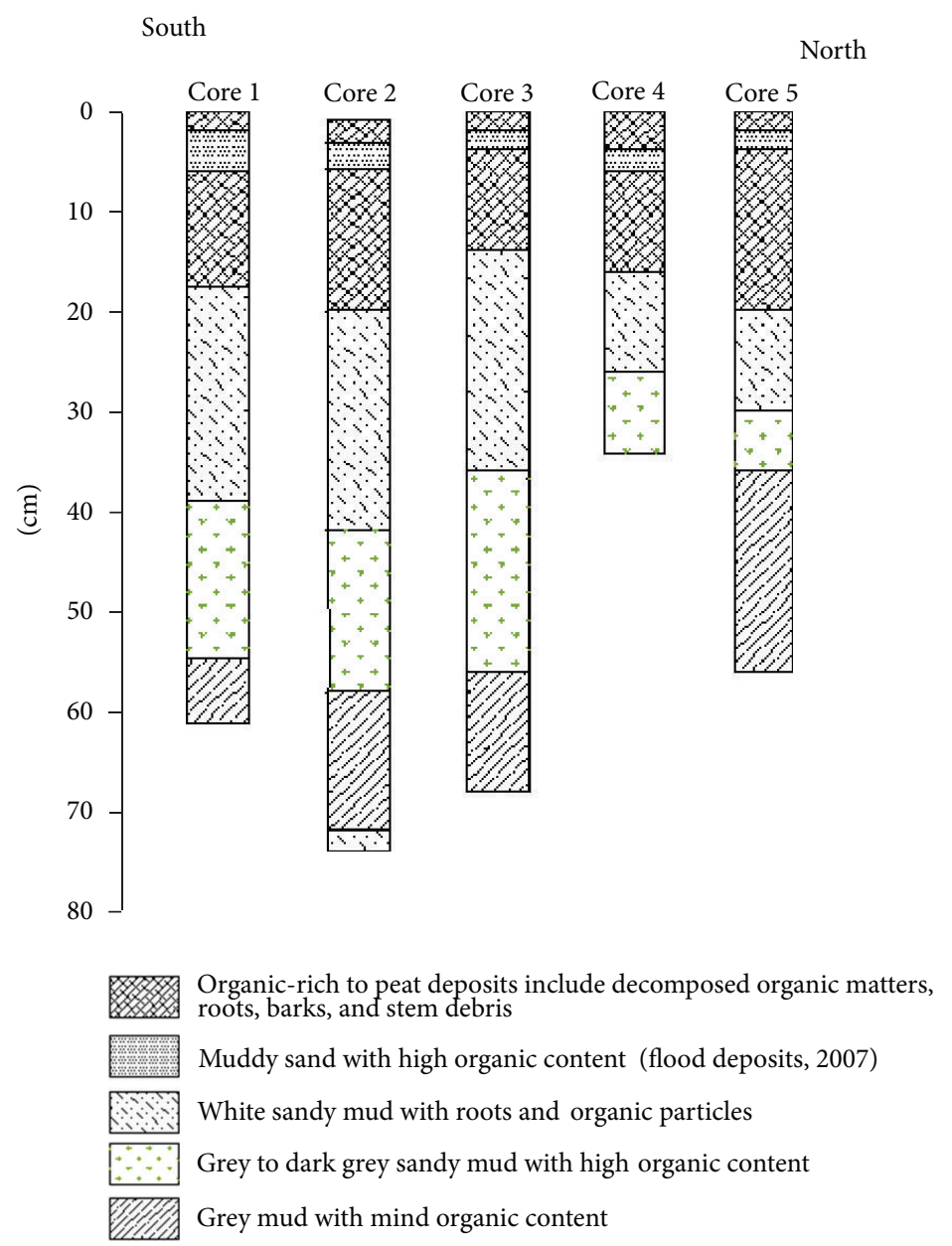

FIgURE 2: Bera Lake sediment stratigraphic layers.

organisms. The sediment is clean to slightly polluted. Contamination in sediments that exceeds the lowest effect level may need management plans.

The severe effect level (SEL) points out heavily polluted condition that is likely to affect the health of sedimentdwelling organisms. Metallic elements concentrations that exceed the severe effect level need further toxicity analysis. In addition, management plans should include controlling the source of the contamination and removing the polluted sediment [22].

The probable effect level (PEL) represents the lowest limit range of chemical concentrations that are usually or always associated with adverse biological effects. Interim sediment quality guideline (ISQG) is national and temporary sediment quality levels to detect adverse biological effects. The ISQG and the PEL can be used to define three ranges of chemical concentrations for a particular chemical [23]. First, those that are rarely (<ISQG), second, occasionally (between the ISQG and the PEL), and third, often ( $>$ PEL) associated with adverse biological effects [8].

The Conesus background SQG (CBSQG) only involves effects to benthic macroinvertebrate species.
2.5. Geoaccumulation Index. Geoaccumulation index (Igeo) (Table 2) can be used to find out metal contamination in sediments, by comparing analysed concentration of metallic elements with background levels of individual metal [21] as follows:

$$
I_{\text {geo }}=\log _{2}\left[\frac{C_{n}}{1.5} \times B_{n}\right]
$$

where $C_{n}$ is given metal levels and $B_{n}$ is the background value of the given element in the study area and 1.5 is the background matrix correction factor owing to lithogenic effects.

2.6. Statistical Analysis. The means and standard deviations were calculated for all individual metallic elements. Statistical significance was set at $95 \%(P=0.05)$ and the calculations were conducted with Microsoft Excel 2011 software and his macro XLSTAT PRO 2011. Metallic elements groups and relative sources were evaluated by Pearson correlation and agglomerative hierarchical cluster analysis. Hierarchical cluster analysis (HCA), an unsupervised technique, was applied to reveal natural grouping between the analyzed metallic 


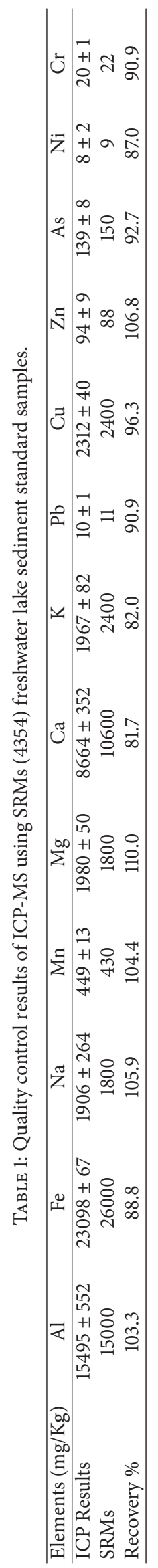


TABLE 2: Classification of Geoaccumulation index [21].

\begin{tabular}{lc}
\hline Igeo range & Classification of pollution \\
\hline 0 & Unpolluted \\
$0-1$ & Unpolluted to moderately polluted \\
$1-2$ & Moderately polluted \\
$2-3$ & Moderately to strongly polluted \\
$3-4$ & Strongly polluted \\
$4-5$ & Strong to very strongly polluted \\
$>5$ & Very strongly polluted \\
\hline
\end{tabular}

elements. In an agglomerative procedure, the main aim is to join similar elements into clusters and to add elements to clusters already found or to join similar clusters [24]. In the present study, the complete linkage rules were used to make the Hierarchical tree. In this method, the distances between the clusters were determined by the greatest distance between any two objects in different clusters (i.e., by the "furthest neighbours"). This method usually performs quite well in cases when the objects actually form naturally distinct "clumps" [24].

\section{Results and Discussion}

3.1. Bera Lake Sediment Layers Stratigraphy. Sediment profile interpretations revealed that the top one meter of Bera Lake sediment contains five separate layers. First layer (1) at the base with grey mud texture, little organic matter in which clay, silt, and sand size grains contributed with an average percentage of $18 \pm 2.5,35 \pm 1.7$, and $48 \pm 2.5$, respectively. It has an average thickness of $25 \mathrm{~cm}$. A second (2) layer comprises of light to dark grey sandy mud texture and has a thickness of $25 \mathrm{~cm}$ on the average. It is characterized by a medium matrix and a plenty of partially rotten roots, barks, stems, charcoals, and other organic debris. Clay, silt, and sand size grains contributed with an average percentage of $11 \pm 2,61 \pm$ 15 , and $28 \pm 15$, respectively. The third layer (3) is comprised of deep erosion-induced deposits with white color and sandy mud texture. Contribution of silt size grains increased to $58 \pm 5$ percent while clay and sand portions reduced to $11 \pm 2$ and $32 \pm 7$ percent on the average. It contains organic material, including various roots, barks, and charcoals. The fourth layer (4), at the top of the sediment profile, is composed of organic-rich to peat deposits and has an average thickness of $25 \mathrm{~cm}$ with a total organic carbon content of 5 to 20 percent. The fifth layer comprises of organic-rich deposits which is formed from terrestrial material which makes the matrix. It has a muddy sand texture, $2-4 \mathrm{~cm}$ thickness and serves as a remarkable signal of the severe flood that hit the area in December 2007 (Figure 2).

3.2. Background Concentration of Metallic Elements in Bera Lake Sediments. Calculation of Geoaccumulation index can only be achieved by background values of metallic elements. Physico-chemical analysis of lower part of the cores (depths of 33-61 cm) of Bera Lake represents sediments which have been deposited during natural and normal conditions. The average values of major and minor elements, therefore, were calculated in these natural layers (Table 3 ). Since wetlands and Bera Lake settled 4,500 BP (Before Present) [16], major and trace metals were accumulated normally. Bera Lake was faced to severe flux of lithogenic and anthropogenic metallic elements over the last four decades that lands were opened for oil palm monoculture.

3.3. Metallic Elements Concentration in Bera Lake Sediments. Minimum, maximum, mean values, standard deviation, and coefficient of variation of each individual metal were calculated. The mean values of $\mathrm{Al}, \mathrm{Fe}, \mathrm{K}, \mathrm{Na}, \mathrm{Mg}$, and $\mathrm{Ca}$ were calculated to be $9.78 \pm 2.7,1.1 \pm 0.6,0.94 \pm 1.3,0.22 \pm 0.01$, $0.14 \pm 0.03$, and $0.1 \pm 0.01 \%$, respectively (Table 4). Besides, the mean values of minor elements in Bera Lake sediments were decreased to $108.7 \pm 14>60 \pm 4>52 \pm 11>39.3 \pm 12>$ $37.4 \pm 7>35 \pm 9>33.2 \pm 3>37 \pm 8>17.5 \pm 4>$ $17 \pm 10>4.3 \pm 3>0.18 \pm 0.01 \mathrm{mg} \mathrm{kg}^{-1}$ for $\mathrm{V}, \mathrm{As}, \mathrm{Cr}, \mathrm{Zn}$, $\mathrm{Li}, \mathrm{Mn}, \mathrm{Sr}, \mathrm{Cu}, \mathrm{Ni}, \mathrm{Pb}, \mathrm{Co}$, and $\mathrm{Cd}$, respectively. The high concentration of $\mathrm{Cr}, \mathrm{Ni}, \mathrm{Cu}, \mathrm{Zn}$, and $\mathrm{Pb}$ was appeared at the south of Bera Lake. The highest mean values of metals Fe, $\mathrm{K}, \mathrm{V}, \mathrm{Mn}, \mathrm{Co}, \mathrm{As}$, and Cd were recorded at the north of the study area. In addition, $\mathrm{Ca}, \mathrm{Mg}, \mathrm{Na}, \mathrm{Li}$, and $\mathrm{Sr}$ concentration were appeared in the highest value at deepest part or middle of Bera Lake. The highest value of $160 \mathrm{mg} \mathrm{kg}^{-1}$ for As was appeared in Core 3 at the outlet of the lake at a depth of $58 \mathrm{~cm}$. In the Bera Lake sediment, the lowest concentration among the metallic elements was recorded for $\mathrm{Cd}$, which has the maximum concentration of $0.2 \mathrm{mg} \mathrm{kg}^{-1}$ at the main sediment inlet of Bera Lake.

A northward increase in concentration of Fe, K, V, Mn, Ni, $\mathrm{Co}, \mathrm{Cr}, \mathrm{Cd}, \mathrm{Zn}$, and $\mathrm{Sr}$ was observed at Bera Lake sediment profiles. In similar condition $\mathrm{Cr}, \mathrm{Ni}, \mathrm{Cu}, \mathrm{Zn}$, and $\mathrm{Pb}$ metals levels declined remarkably. A dramatic upward variation $(\mathrm{CV}$, $48-78 \%$ ) in the metallic elements levels was observed in sediment column of Bera Lake (Figure 3). Results show that chemical composition trends were controlled significantly by environmental changes and the physico-chemical conditions of the Bera Lake basin. The $\mathrm{Mn} / \mathrm{Fe}$ ratio [25] as an indicator of redox condition asserting that low concentrations of $\mathrm{Mn}$ coincided with low $\mathrm{Mn} / \mathrm{Fe}$ ratios and high TOC concentrations The $\mathrm{Mn} / \mathrm{Fe}$ ratio was calculated $0.007,0.0027,0.003$, 0.018, and 0.003 for Core 1, Core 2, Core 3, Core 4, and Core 5 , respectively. An upward decrease in $\mathrm{Mn} / \mathrm{Fe}$ ratio was found at all Bera Lake sediment profile. $\mathrm{Mn}^{2+}$ mainly precipitates as $\mathrm{MnCO}_{3}$ [25] and is therefore also more dependent on $\mathrm{pH}$. Condition at Bera Lake was found to be acidic and $\mathrm{pH}$ recorded in the present study as $<5$, was agreed with previous study [17]. Low concentration of $\mathrm{Mn}$ was found in acidic conditions at Bera Lake. As $\mathrm{pH}$ decreased, $\mathrm{MnCO}_{3}$ becomes less stable and more $\mathrm{Mn}$ was mobilized reducing the $\mathrm{Mn} / \mathrm{Fe}$ ratio consequently.

3.4. Correlation and Cluster Analysis. Countless studies have supported the importance of statistical analysis to evaluate the likenesses and dissimilarities in sources, fate, and distribution analysis of metals [24, 26]. Graphic interpoint distance between all studied metallic elements at Bera Lake 


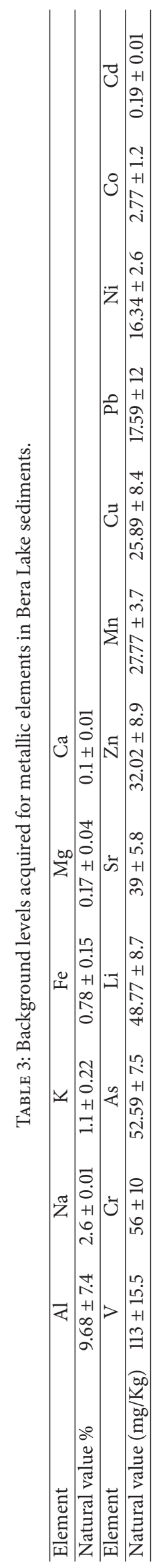


TABLE 4: The mean values of metallic elements in Bera Lake sediments.

\begin{tabular}{|c|c|c|c|c|c|c|c|c|c|c|c|c|}
\hline Element & $\mathrm{Al}$ & $\mathrm{Fe}$ & $\mathrm{K}$ & $\mathrm{Na}$ & $\mathrm{Mg}$ & $\mathrm{Ca}$ & & & & & & \\
\hline $\begin{array}{l}\text { Mean } \\
\text { value \% }\end{array}$ & $9.78 \pm 2.7$ & $1.10 \pm 0.6$ & $0.94 \pm 1.3$ & $0.22 \pm 0.01$ & $0.14 \pm 0.03$ & $0.1 \pm 0.01$ & & & & & & \\
\hline Element & $\mathrm{V}$ & As & $\mathrm{Cr}$ & $\mathrm{Zn}$ & $\mathrm{Li}$ & $\mathrm{Mn}$ & $\mathrm{Sr}$ & $\mathrm{Cu}$ & $\mathrm{Ni}$ & $\mathrm{Pb}$ & Co & $\mathrm{Cd}$ \\
\hline $\begin{array}{l}\text { Mean } \\
\text { value } \\
(\mathrm{mg} / \mathrm{Kg})\end{array}$ & $108.7 \pm 14$ & $59.89 \pm 4$ & $51.79 \pm 11$ & $39.31 \pm 12$ & $37.38 \pm 7$ & $34.68 \pm 9$ & $33.18 \pm 3$ & $26.57 \pm 8$ & $17.45 \pm 4$ & $16.89 \pm 10$ & $4.27 \pm 3$ & $0.18 \pm 0.01$ \\
\hline
\end{tabular}

sediment columns has been represented in the form of twodimensional plot or a dendogram and is given in Figure 4. Clusters analyzed are based on complete linkage. Clusters with significant positive correlations between the nearest metallic elements and similar clusters plotted at minimum distance. On the other hand, significant negative correlation between analyzed metallic elements was plotted at maximum distances in separate clusters.

Similarities and dissimilarities between analyzed metallic elements at the south of Bera Lake have been represented in the three classes (Figure 4(a)). Class 1 representing a strong correlation was observed between $\mathrm{Li}, \mathrm{Al}, \mathrm{K}, \mathrm{Mg}, \mathrm{Sr}, \mathrm{Ca}, \mathrm{Fe}$, $\mathrm{Na}, \mathrm{Zn}$, and $\mathrm{Cd}$ having $r$-values exceeding 0.85 . In addition, $\mathrm{Cu}, \mathrm{Ni}$, and $\mathrm{Cr}$ have clustered in class 2 with $r$-values between 0.72 and 0.8 are closest metallic element to class 1 . The furthest metallic elements to classes 1 and 2 are $\mathrm{Co}, \mathrm{Mn}, \mathrm{As}, \mathrm{Pb}$, and $\mathrm{V}$ which have clustered in class 3 having a weak positive correlation with other analyzed elements.

Metallic elements have represented different groupings at the middle and at the deepest part of Bera Lake (Figure 4(b)). Class 1 included $\mathrm{Pb}, \mathrm{Co}$, As, and $\mathrm{Cu}$ which were clustered with moderate to strong positive similarities. Very strong correlation which has $r$-values exceeding 0.9 between $\mathrm{Na}, \mathrm{Li}$, $\mathrm{K}, \mathrm{Mg}, \mathrm{Sr}, \mathrm{Cr}$, and $\mathrm{Al}$ is dominated in class 2 . However, class 3 indicates metallic elements which represent moderate to strong positive isotropy with organic matters and nitrogen. Class 3 is comprised of two groups; the first group includes $\mathrm{Ca}, \mathrm{Ni}, \mathrm{Cd}$, and TOC and the other comprises TN, Fe, Zn, Mn, and V. In other words, class 3 highlighted metallic elements which had been enriched and accumulated when organic carbon and nitrogen enriched. At the margin of the middle of Bera Lake (Figure 4(d)), metallic element was slightly clustered in the different classes. Lithogenic elements of $\mathrm{Mg}$, $\mathrm{Al}, \mathrm{Fe}, \mathrm{Na}, \mathrm{K}, \mathrm{Cr}, \mathrm{Li}$, and $\mathrm{Sr}$ have clustered in the class 1 with similarity exceeding 0.7 . Class 2 is a tree in which metallic elements such as $\mathrm{Mn}, \mathrm{V}, \mathrm{Pb}, \mathrm{Zn}$, and $\mathrm{Cu}$ have grouped with a moderate positive similarity. Finally, metallic elements like $\mathrm{Ca}, \mathrm{Co}, \mathrm{As}, \mathrm{Cd}$, and $\mathrm{Ni}$ have clustered in class 3 with a weak to moderate similarity.

Similar to the middle of Bera Lake, a group of organicbond metallic elements like $\mathrm{Co}, \mathrm{Mn}, \mathrm{Zn}, \mathrm{Fe}, \mathrm{As}, \mathrm{Ni}$, and $\mathrm{Cd}$ have clustered in class 1 at the northern part of the study area (Figure 4(c)). The strongest correlations with $r$ values exceeding 0.9 were observed between Co, Mn, and TN. Similar correlation has appeared between TOC and Fe. Class 2 is a small tree in which $\mathrm{Ca}, \mathrm{Cu}$, and $\mathrm{V}$ have clustered with closest distance to class 1 . A strong positive correlation $(r$ values $>0.7$ ) was observed between the lithogenic group of metallic elements; $\mathrm{Al}, \mathrm{Li}, \mathrm{K}, \mathrm{Mg}, \mathrm{Cr}, \mathrm{Sr}$, and $\mathrm{Pb}$ in class 3. A reverse accumulation trend in clustered metallic elements was obtained between class 3 and classes 1 and 2. General trend of metallic elements increase was recognized in the sediment profile of semiclosed area at the northwest area of Bera Lake (Figure 4(e)). Elements such as Fe, Mn, Zn, Ni, $\mathrm{Co}, \mathrm{As}, \mathrm{Cd}$, and $\mathrm{Cr}$ are grouped in class 1 with a moderate to strong positive $r$-value. Class 2 includes $\mathrm{Mg}, \mathrm{Al}$, and Li metals which implied maximum positive correlation. In this part of lake, metals ( $\mathrm{Na}, \mathrm{K}, \mathrm{Sr}, \mathrm{Cu}, \mathrm{Pb}, \mathrm{V})$ showed negative correlation when classified with other metals in class 1 and 2.

3.5. Assessment of Metal Contamination. Index of Geoaccumulation [21] for all individual metallic elements was settled $0-1$ at five sections of Bera Lake. Bera Lake sediment was classified from unpolluted to moderately polluted category except the uppermost layer of the sediment profile at the middle of Bera Lake which is moderate to extremely polluted by Co. Sediment quality indices were compared with Fe, As, $\mathrm{Ni}, \mathrm{Cr}, \mathrm{Cd}, \mathrm{Zn}, \mathrm{Cu}$, and $\mathrm{Pb}$ level to assess the pollution status in Bera Lake. Selected metals were recognized to be the most common metals for being compared with the threshold limits of the standard levels. Thresholds levels for other metallic elements were not available in the selected guidelines.

Overall $\mathrm{Zn}$ and $\mathrm{Cd}$ values were plotted beneath the LEL in whole Bera Lake sediment profile. However, enrichment was remarked in $\mathrm{Zn}$ and $\mathrm{Cd}$ levels at the north of study area. Studying the $\mathrm{Cu}$ level in different parts of Bera Lake pointed out a slight contamination. Copper level appeared upper than the LEL and SBSQ limits, especially at the top of Cores 4 and 5 and in the middle of Core 2 , and far from SEL (120 $\left.\mathrm{mg} \mathrm{kg}^{-1}\right)$.

Bera Lake sediment was assessed as slightly to moderately contaminated by Ni metals, especially at the south and northwest sections. Results showed that the background values of $\mathrm{Ni}$ were plotted remarkably beneath the LEL; nonetheless, their concentrations increased to upper than the LEL value by the increase of the organic matter in the uppermost layers.

Standard levels were compared with $\mathrm{Pb}$ levels from different parts of the study area. Bera Lake sediments were slightly contaminated by $\mathrm{Pb}$ metal at Core 1 , Core 4 , and Core 5 positions. Lead levels were plotted upper than LEL $\left(31 \mathrm{mg} \mathrm{kg}^{-1}\right)$ and so far from SEL $\left(120 \mathrm{mg} \mathrm{kg}^{-1}\right)$ limit. Bera Lake sediment profile pictured a general upward decline in the $\mathrm{Pb}$ level except at Core 4 whose trend was reveresed.

Iron was recognized as a plentiful metal in Bera Lake sediment. Sediment quality assessment depicts that the concentrations of Fe at Core 2, Core 4, and 5 were plotted beneath LEL and ISQG levels. On the other hand, iron concentration 


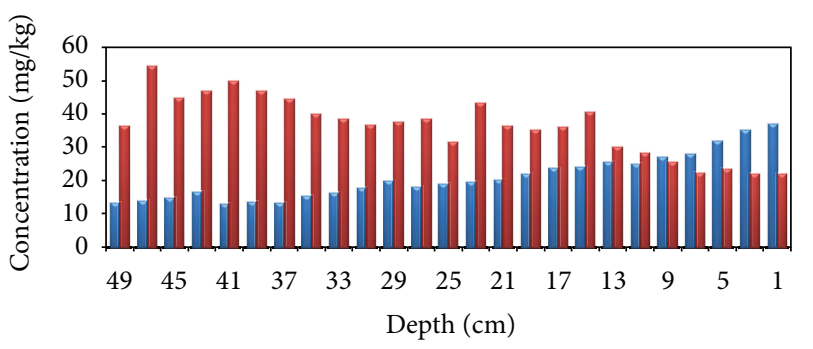

- $\mathrm{Ni}$

- $\mathrm{Pb}$

Figure 3: Clear upward variations of $\mathrm{Ni}$ and Fe in Bera Lake sediment column (Core 5).

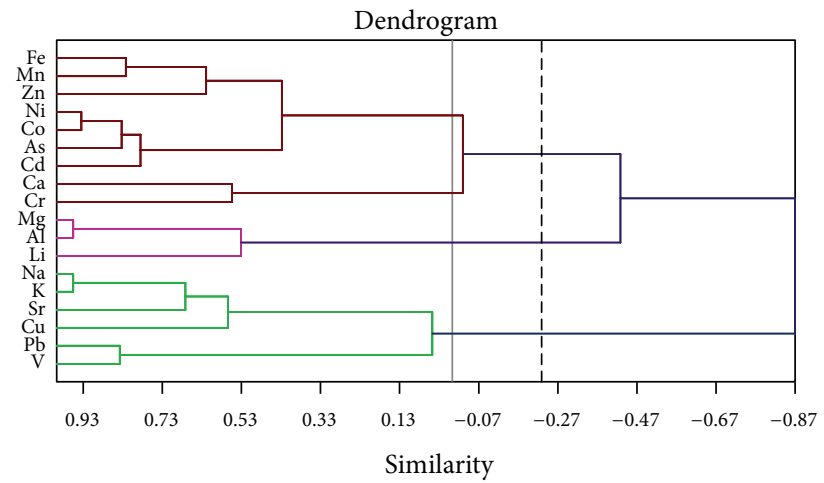

(a)

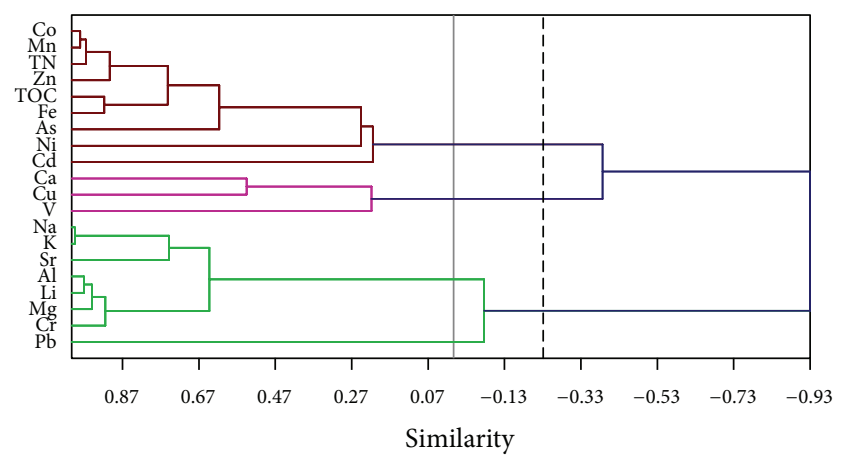

(c)

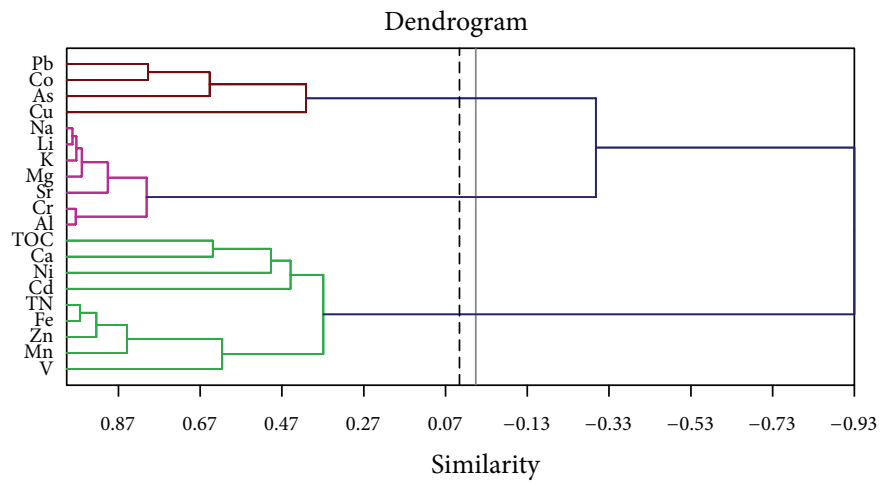

(b)

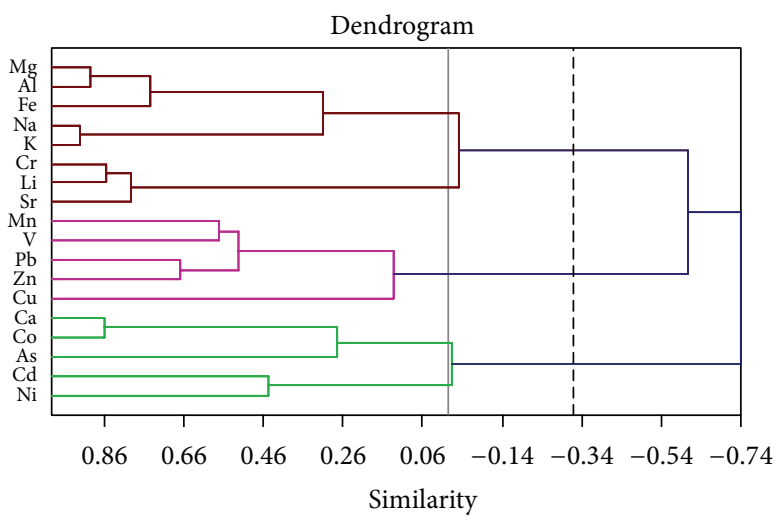

(d)

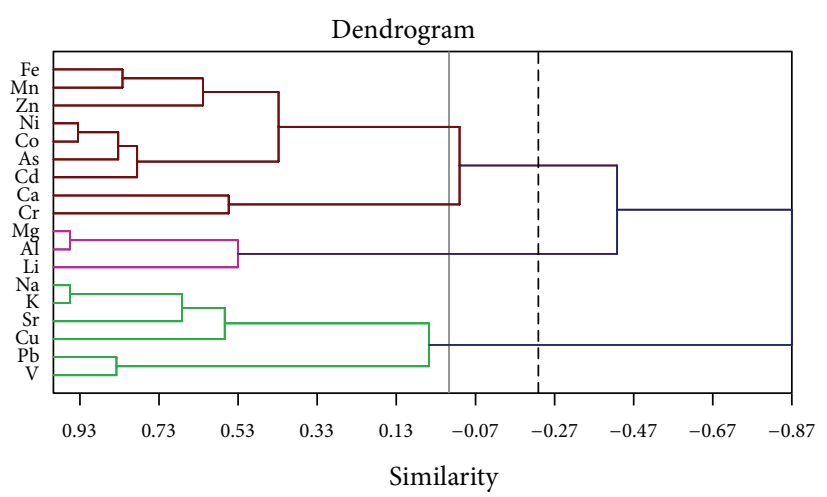

(e)

FIGURE 4: Metallic elements clustering results in the different parts of Bera Lake. 
at the top of Cores 2 and 3 was plotted upper SEL and sediments which was contaminated severely by $\mathrm{Fe}$ metal (Figure 5).

Bera Lake sediment assessment using standard limits revealed a significant contamination by arsenic metalloid at all sampling locations (Figure 5). Maximum, minimum, and the average values of As at five studied cores gained upper than severe effective level. Further, arsenic background value was calculated upper than LEL at all the sections of Bera Lake. In addition, chromium levels were plotted upper than LEL, ISQG, and CBSQG threshold limits at the whole Bera Lake sediments. Also, chromium caused moderate pollution at the depths of 15-40 assessed in Bera Lake sediment profile (Figure 5).

Bera lake sediment composition reveals parent rock composition and land use effects at the catchment area. Seemingly, Al-bearing deposits were remarkably supported by Bera Formation (Permian) and Triassic granite intrusions. These rock units have repeatedly altered and a thick white colour in the secondary mineral place has been created. In addition, Quaternary conglomerate with different thickness was outcropped especially at the west and northwest of the study area. This stratigraphic unit is mainly responsible to promote $\mathrm{Fe}$ content in soil and sediment profiles of the study area. Iron-rich ores at Bera Lake catchment [27] are responsible for increasing the $\mathrm{Fe}$ content in the sink areas. FELDA is the main executive government agency for land developments in Malaysia since 1995 [28].

Almost $292.86 \mathrm{~km}^{2}$ of the original forest was converted to oil palm and rubber plantations during the five phases of land development project by FELDA during 1970-1995 at Bera Lake catchment. Land has to disclose for intense chemical weathering for 12-14 months for each 2,000 hectare oil palm plantation in a tropical climate [29]. Deposition of erosion-induced sediments at the Bera Lake basin has started with deposition of a white sandy mud (Layer 3). Cluster analysis has greatly revealed vertical variation of sediment composition. Lithogenic elements ( $\mathrm{Na}, \mathrm{K}, \mathrm{Sr}, \mathrm{Al}, \mathrm{Li}, \mathrm{Mg}, \mathrm{Cr}$, and $\mathrm{Pb}$ ) have been mainly associated with deposition of white sandy mud. Grain size analysis properly showed a significant positive correlation between silt size sediment and lithogenic metals. In the other word, a simultaneous increasing in the silt size sediment and the lithogenic metals concentration has been concluded. This isotropy was observed at all sections of Bera Lake. Intense chemical weathering and sediment supply of exposed rocks during FELDA land development projects were the main cause of remarkable isotropy between deposition of white sandy mud and these metals.

Oil palm plantation accumulates 8.3 tons of biomass each year, which is almost 2.5 tons higher than what a rain forest annually piles up. In addition, annual dry matter productivity of oil palm is 36.5 tons compared to a rain forest with 25.7 tones only [13]. Division of Bera Lake sediments showed an organic-rich peat layer, with an average thickness of $20 \mathrm{~cm}$, at top of sediment profile. Organic-rich sediment was deposited extensively at Bera Lake after the new forest and oil palm development states were stabilized. Twenty percent of organic matter in peat layer involves roots, barks, stems, charcoals, and other organic debris. These materials are well known for microbial growth and absorption of inorganic elements, which then transform to different organic forms [8]. Cluster analysis clearly marks correlation between deposition of organic-rich sediments and a specific group of metallic elements (Fe, Mn, As, Zn, Cu, Ni, V, Co, Ca, and Cd).

Vanadium is known as a sign of oil pollution which was also classified in this cluster and it should be responsible for the spread of organic-bond metallic elements [30]. Results revealed that vanadium level in studied samples is close to its concentration in shales (100-130 $\mathrm{mg} \mathrm{kg}^{-1}$, [30]) which is one of dominated lithology in the catchment area. Furthermore, the increase in concentration of $\mathrm{V}$ coincided with the beginning of FELDA land development phases. Vehicle traffic could play an important role to increase trace metals concentration in drainages especially arsenic and vanadium [31]. Probably, heavy vehicles exhaust during land preparation and plantation stages might be an important reason for the increase of As and $\mathrm{V}$ in soil and sediments.

Arsenic associated significantly in the contamination of Bera Lake sediments. Arsenic is present naturally in the aquatic and terrestrial environments owing to weathering and eroding of rock and soil. Nonpoint sources of origin such as agricultural and geological formations of study area have mainly contributed to accumulation of As at the area. Alternatively, deforestation and land burning during land development for oil palm plantations have also increased the level of arsenic content at Bera Lake deposits. A further study is needed to evaluate the distribution of arsenic contents at Bera Lake catchment. Arsenic appeared in organic-bond fraction of metallic elements, indicating contribution of organic matters in elemental enrichment at Bera Lake.

Iron and manganese oxides have been well recognized [8] for their abilities to absorb and enrich other metallic elements such as $\mathrm{As}, \mathrm{Cr}, \mathrm{Cu}$, and $\mathrm{Ni}$. They play an important role to the extent that their deposition occurred in the bed sediments. The fate and persistence of $\mathrm{As}, \mathrm{Cr}, \mathrm{Cu}$, and $\mathrm{Ni}$ intricately connected with fate and persistence of iron oxides. The activity of Fe/Mn oxide is influenced by different factors such as redox conditions, $\mathrm{pH}$, and microbial activity in the sediments. Therefore, the sediments act as an important route to metal exposure for aquatic organisms. The metallic elements which include $\mathrm{As}, \mathrm{Cr}, \mathrm{Cu}$, and $\mathrm{Ni}$ have also accounted for adversebiological effects in organic-rich sediments of Bera Lake. Arsenic has numerous adverse effects such as decline in the benthic invertebrate, mortality expansion, and behavioural changes [8]. Benthic organisms were exposed to both particulate and dissolved forms of these metallic elements in interstitial and surface waters. They were also exposed to sediment-bond As through surface contact and ingestion of sediment. Inorganic metallic elements are the predominant form in the sediment, the water column, and the interstitial water. Microorganisms in the sediments can transform inorganic forms of metallic elements into organic forms, which can perfectly gather in aquatic organisms. Microorganisms provide the biochemical link in the cycling of metals in aquatic systems. The methylated forms found in interstitial waters are the by products of microbial action [8]. 


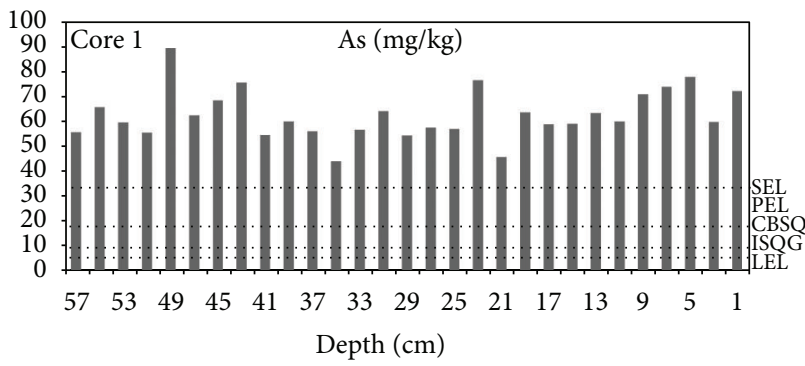

(a)

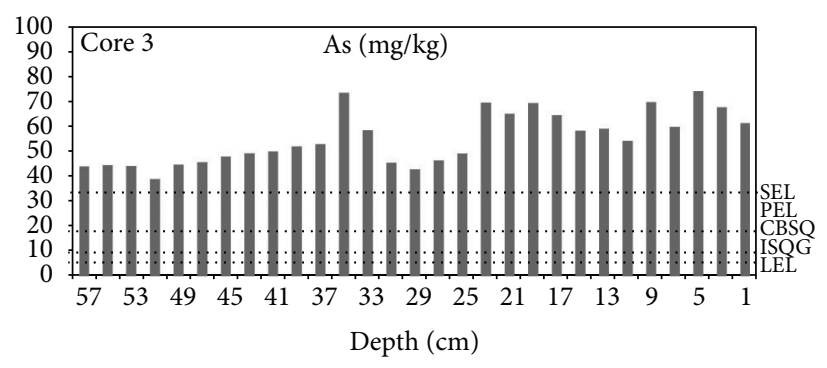

(c)

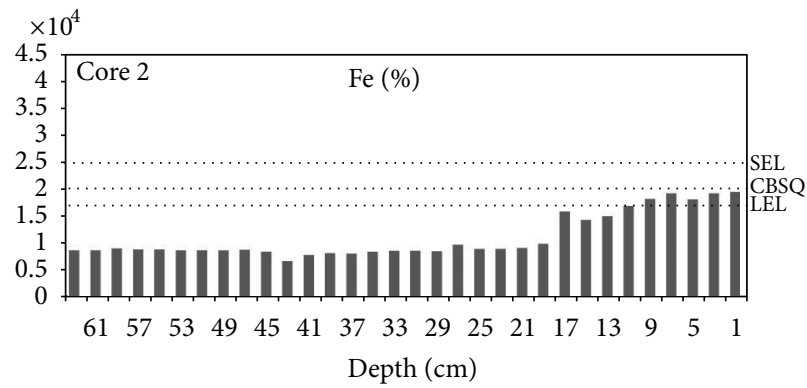

(e)

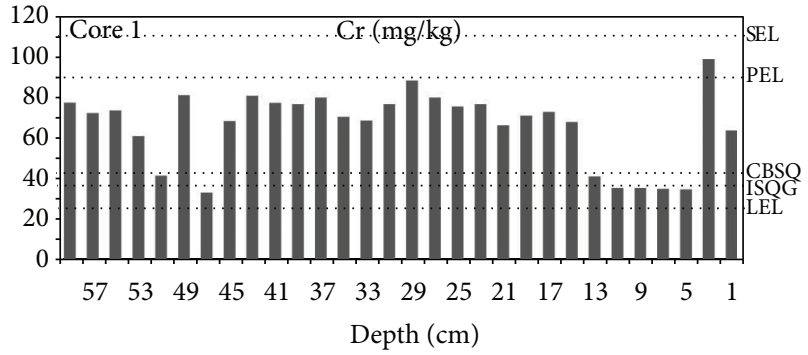

(g)

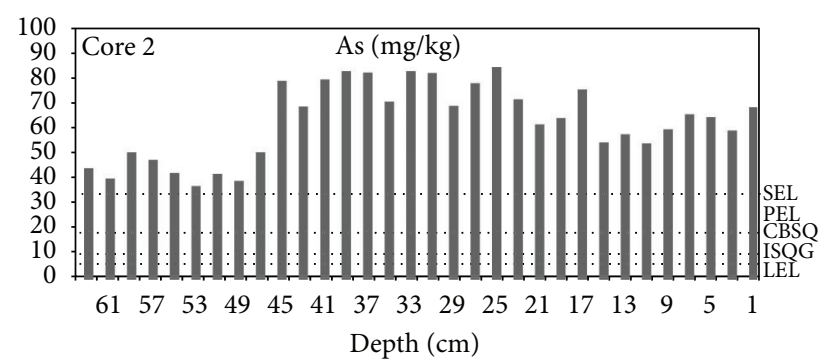

(b)

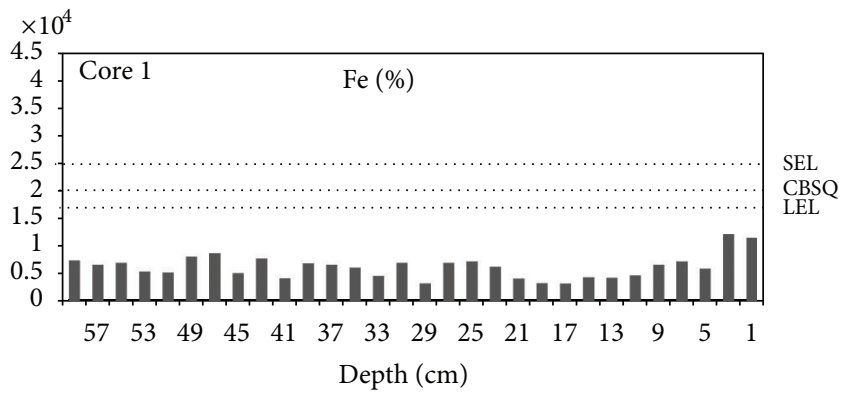

(d)

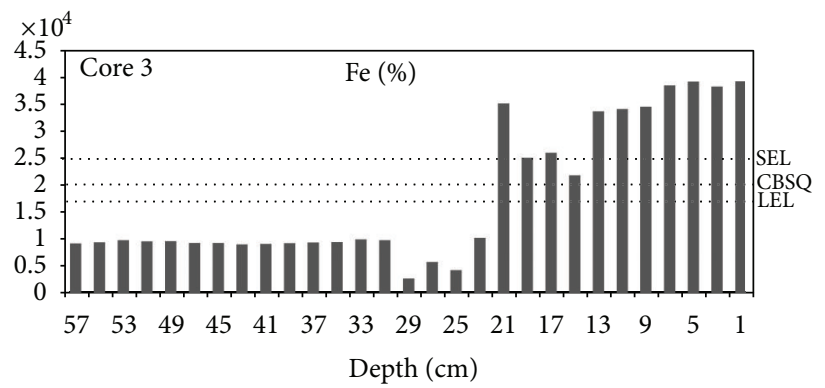

(f)

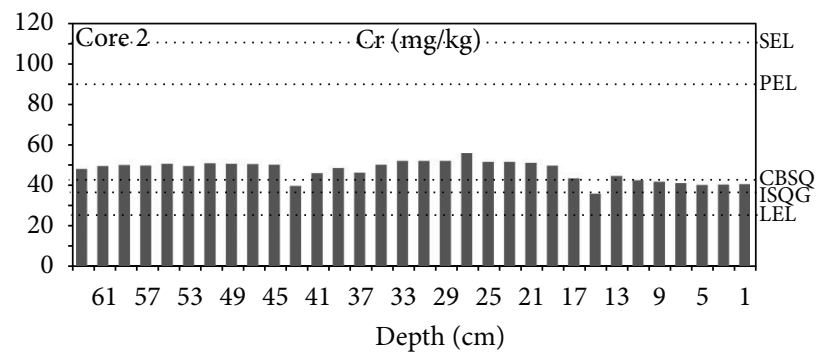

(h)

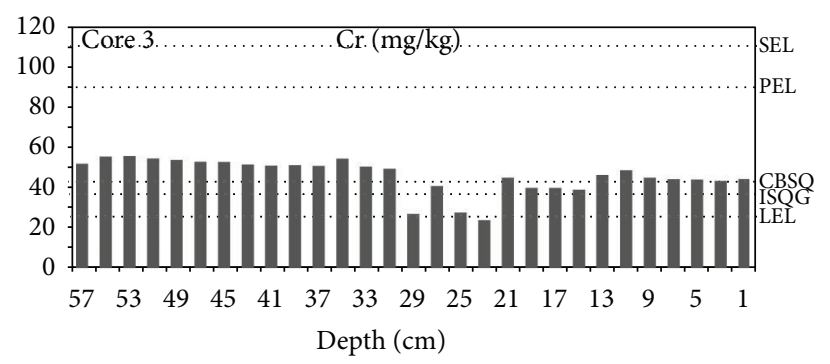

(i)

Figure 5: Pollution status of Bera Lake sediments caused by three metallic elements (As, Fe, and Cr). 
The sensitivity of aquatic species for heavy metals can account for adverse effects of them. Due these adverse effects dose-response model can be efficiently utilized for heavy metal exposure at a particular site. Bera Lake is sink areas which provide highly enriched exposure of heavy metals to aquatic organisms. The present study has revealed the acidic condition of the lake, with an average $\mathrm{pH}<5$ and has agreed with the previous study [17]. The acidic condition acts as a preservative for organic matter and thus provides suitable media for microorganisms. These microorganisms promote metals exposure to aquatic life. Therefore, organicrich deposits are the main cause of increased bioavailability and uptake rates of contaminants at Bera Lake.

\section{Conclusions}

The present research has notably revealed Bera Lake sediment quality status and reasoning fluxes of metallic elements into the Lake. Assessment of Bera Lake sediment has remarkably proved capability of SQG than the Geoaccumulation index. Statistical analysis has greatly demonstrated distinctive groups of metallic elements in the sediment column which have accumulated and enriched in similar chemical conditions. This analysis marks two major groups of metallic elements bonded to the terrestrial and organic-rich sediments. The first group includes $\mathrm{Li}, \mathrm{Al}, \mathrm{Pb}, \mathrm{Cu}, \mathrm{Cr}, \mathrm{Na}, \mathrm{Mg}, \mathrm{Sr}$, and $\mathrm{K}$ metal. Distinctive metallic elements fluxes in the Lake have significantly appeared along the five cores especially in white sand mud (Layer 3). Similarly intense chemical weathering of Al-bearing rock units during FELDA land development phases has also supported the sandy mud supply at Bera Lake. The second group which includes $\mathrm{Fe}, \mathrm{Mn}, \mathrm{As}, \mathrm{Zn}, \mathrm{Cu}, \mathrm{Ni}$, $\mathrm{Co}, \mathrm{Ca}$, and $\mathrm{Cd}$ has mainly associated with the deposition of organic-rich sediments particularly at uppermost layer of the Lake sediment column. Establishment of mature oil palm plantations with high organic matter productivity since 1995 has controlled accumulation of organic-rich sediments. SQGs have pointed to severe pollution of Bera Lake deposits by arsenic and in the north of the catchment by iron. In addition, Bera Lake sediment profile is moderately polluted by $\mathrm{Cu}, \mathrm{Cr}$, and $\mathrm{Ni}$ metals. There is no significant impact of pollution remarked for $\mathrm{Zn}, \mathrm{Cd}, \mathrm{Cu}$, and $\mathrm{Pb}$ metals at Bera Lake. A comprehensive management plan is required for sustainable land use scheme at the catchment area. Furthermore, better management practices are required for the cleanup Bera Lake sediments from metallic elements in order to protect flora, and fauna as well as human health.

\section{Conflict of Interests}

The authors declare that they have no conflict of interests.

\section{Authors' Contribution}

All authors have read and confirmed the paper. This research has been accomplished by a team work and authors have contributed especially in the field and experimental studies.
M. Gharibreza has played main role in this research and M. A. Ashraf helped in the interpretations and analytical studies.

\section{Acknowledgments}

The authors are grateful to the Institute of Research Management and Monitoring (IPPP), University of Malaya for the funding to accomplish this valuable research. They are also grateful to Mr. Mohd Yusri Abdul Rahim (Hydrology lab. Manager), for his kind gesture during ICP-MS operation. The authors are grateful to Mr. Fateh Bin Ngaliman (CHN lab) for his help during nutrient analysis.

\section{References}

[1] F. L. Xu, "Application of ecological and thermodynamic Indicators for the assessment of lake ecosystem health," in Handbook of Ecological Indicators for Assessment of Ecosystem Health, CRC Press, New York, NY, USA, 1st edition, 2005.

[2] G. F. Birch and T. D. Hogg, "Sediment quality guidelines for copper and zinc for filter-feeding estuarine oysters?" Environmental Pollution, vol. 159, no. 1, pp. 108-115, 2011.

[3] L. M. Buruaem, M. A. Hortellani, J. E. Sarkis, L. V. CostaLotufo, and D. M. S. Abessa, "Contamination of port zone sediments by metals from large marine ecosystems of Brazil," Marine Pollution Bulletin, vol. 64, no. 3, pp. 479-488, 2012.

[4] A. Ikem and S. Adisa, "Runoff effect on eutrophic lake water quality and heavy metal distribution in recent littoral sediment," Chemosphere, vol. 82, no. 2, pp. 259-267, 2011.

[5] S. L. Simpson, G. E. Batley, I. L. Hamilton, and D. A. Spadaro, "Guidelines for copper in sediments with varying properties," Chemosphere, vol. 85, no. 2, pp. 1487-1495, 2011.

[6] M. Varol and B. Şen, "Assessment of nutrient and heavy metal contamination in surface water and sediments of the upper Tigris River, Turkey," CATENA, vol. 92, no. 1, pp. 1-10, 2012.

[7] L. Viñas, M. Angeles Franco, J. Antonio Soriano, J. José González, J. Pon, and J. Albaigés, "Sources and distribution of polycyclic aromatic hydrocarbons in sediments from the Spanish northern continental shelf. Assessment of spatial and temporal trends," Environmental Pollution, vol. 158, no. 5, pp. 1551-1560, 2010.

[8] CCME, "Protocol for the derivation of Canadian sediment quality guidelines for the protection of aquatic life," ECGaS Division editor, Environment Canada, Guidelines Division, Technical Secretariat of the CCME Task Group on Water Quality Guidelines, Ottawa, Canada.

[9] CBSQG, Consensus-Based Sediment Quality Guidelines, CSS Team editor, Wisconsin, Wis, USA, 2003.

[10] S. Caeiro, M. H. Costa, T. B. Ramos et al., "Assessing heavy metal contamination in Sado Estuary sediment: an index analysis approach," Ecological Indicators, vol. 5, no. 2, pp. 151-169, 2005.

[11] K. Sultan and N. A. Shazili, "Distribution and geochemical baselines of major, minor and trace elements in tropical topsoils of the Terengganu River basin, Malaysia," Journal of Geochemical Exploration, vol. 103, no. 2-3, pp. 57-68, 2009.

[12] T. S. Ling, Analysis and Assessment of Sediment QuAlity in a Typical Malaysian River, Faculty of Civil Engineering, University Teknologi Malaysia, Kuala Lumpur, Malaysia, 2007.

[13] MPOC, Palm Oil, Tree of Life, M. P. O. C. Official editor, Malaysian Palm Oil Council Official, 2007. 
[14] G. Chong, Tasek Bera: Past, Present and Future in Colloquium on Lakes and Reservoir Management: Status and Issues, A. Anton Ed., Minstry of Natural Resources and Environment, Putrajaya, Malaysia, 2007.

[15] C. S. Hutchison and D. N. K. Tan, Geology of Peninsular Malaysia, The University of Malaya and The Geological Scoiety of Malaysia, Kuala Lumpur, Malaysia, 2009.

[16] R. J. Morley, "The palaeoecology of Tasek Bera, a lowland swamp in Pahang, West Malaysia," Singapore Journal of Tropical Geography, vol. 2, no. 1, pp. 49-56, 1981.

[17] R. A. J. Wüst and R. M. Bustin, "Late Pleistocene and Holocene development of the interior peat-accumulating basin of tropical Tasek Bera, Peninsular Malaysia," Palaeogeography, Palaeoclimatology, Palaeoecology, vol. 211, no. 3-4, pp. 241-270, 2004.

[18] H. M. Kingston and L. B. Jassie, Introduction to Microwave Sample Preparation Theory and Practice, ACS Proffessional Reference Book Series, American Chemical Society, Washington, DC, USA, 1988.

[19] S. J. Blott and K. Pye, "Gradistat: a grain size distribution and statistics package for the analysis of unconsolidated sediments," Earth Surface Processes and Landforms, vol. 26, no. 11, pp. 12371248, 2001.

[20] G. T. Wernimont and W. Spendley, Use of Statistics to Develop and Evaluate Analytical Methods, AOAC International, Arlington, Va, USA, 1985.

[21] G. Müller, "Schwermetalle in Sedimenten des Rheins," Veränderungen Seit Umschau, vol. 79, no. 1, pp. 778-783, 1979.

[22] D. Persaud, R. Jaagumagi, and A. Hayton, Guidelines for the Protection and Management of Aquatic Sediment Quality, Water Resources Branch, Ministry of the Environment, Ontario, Canada, 1993.

[23] L. Connie, K. A. Gaudet, R. A. Keenleyside, S. L. Kent, and S. M. P. Wong, "How should numerical criteria be used? The Canadian approach," Human and Ecological Risk Assessment, vol. 1, no. 1, pp. 19-28, 1995.

[24] J. W. Einax, H. W. Zwanziger, and S. Geib, Chemometrics in Environmental Analysis, Wiley-VCH, Weinheim, Germany, 1st edition, 2007.

[25] K. A. Koinig, W. Shotyk, A. F. Lotter, C. Ohlendorf, and M. Sturm, "9000 years of geochemical evolution of lithogenic major and trace elements in the sediment of an alpine lakethe role of climate, vegetation, and land-use history," Journal of Paleolimnology, vol. 30, no. 3, pp. 307-320, 2003.

[26] R. G. Brereton, Applied Chemometricts for Scientists, John Wiley \& Sons, Chichester, UK, 2007.

[27] S. MacDonald, Geology and Mineral Resources of the Lake Chini, Sungia Bera, Sungai Jeram Area of South Central Pahang, G. S. O. Malaysia editor, Ministry of Lands and Mines Malaysia, Kuala Lumpur, Malaysia, 1970.

[28] I. E. Henson, Environmental Impacts of Oil Palm Plantations in Malaysia, Palm Oil Research Institute of Malaysia, Kuala Lumpur, Malaysia, 1994.

[29] K. T. Tan, K. T. Lee, A. R. Mohamed, and S. Bhatia, "Palm oil: addressing issues and towards sustainable development," Renewable and Sustainable Energy Reviews, vol. 13, no. 2, pp. 420-427, 2009.

[30] M. Anke, "Vanadium - an element both essential and toxic to plants, animals and humans?" Anales de la Real Academia Nacional de Farmacia, vol. 70, no. 4, pp. 961-999, 2004.

[31] J. M. Peckenham, J. S. Kahl, and A. Amirbahman, The Impact of Vehicle Traffic on Water Quality, Acadia National Park. U.S.
Department of the Interior, Mount Desert Island, Me, USA, 2006. 

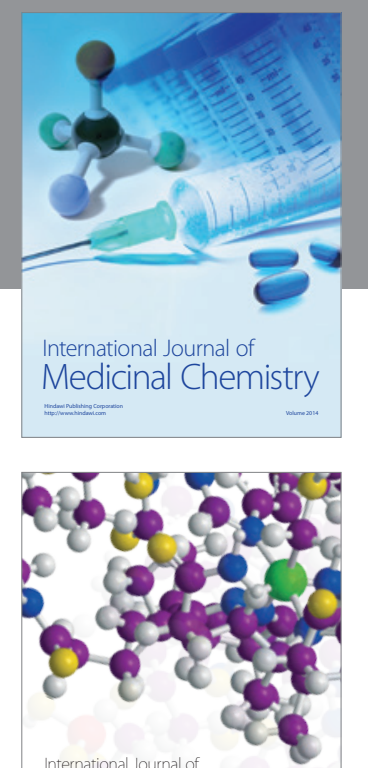

\section{Carbohydrate} Chemistry

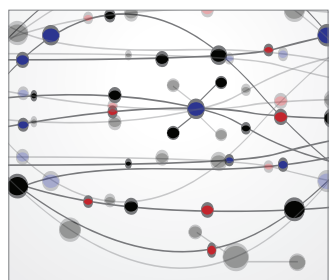

The Scientific World Journal
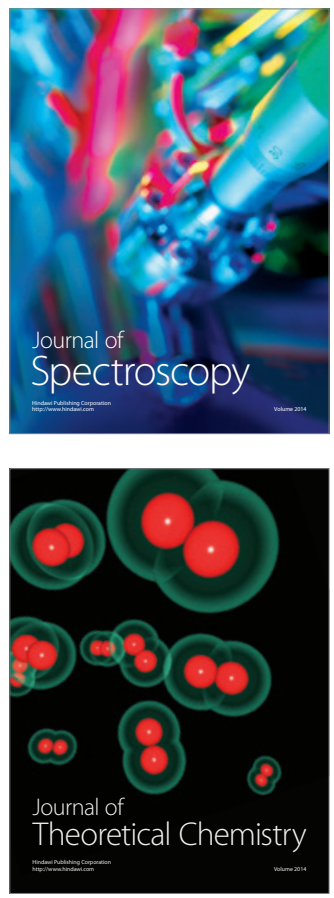
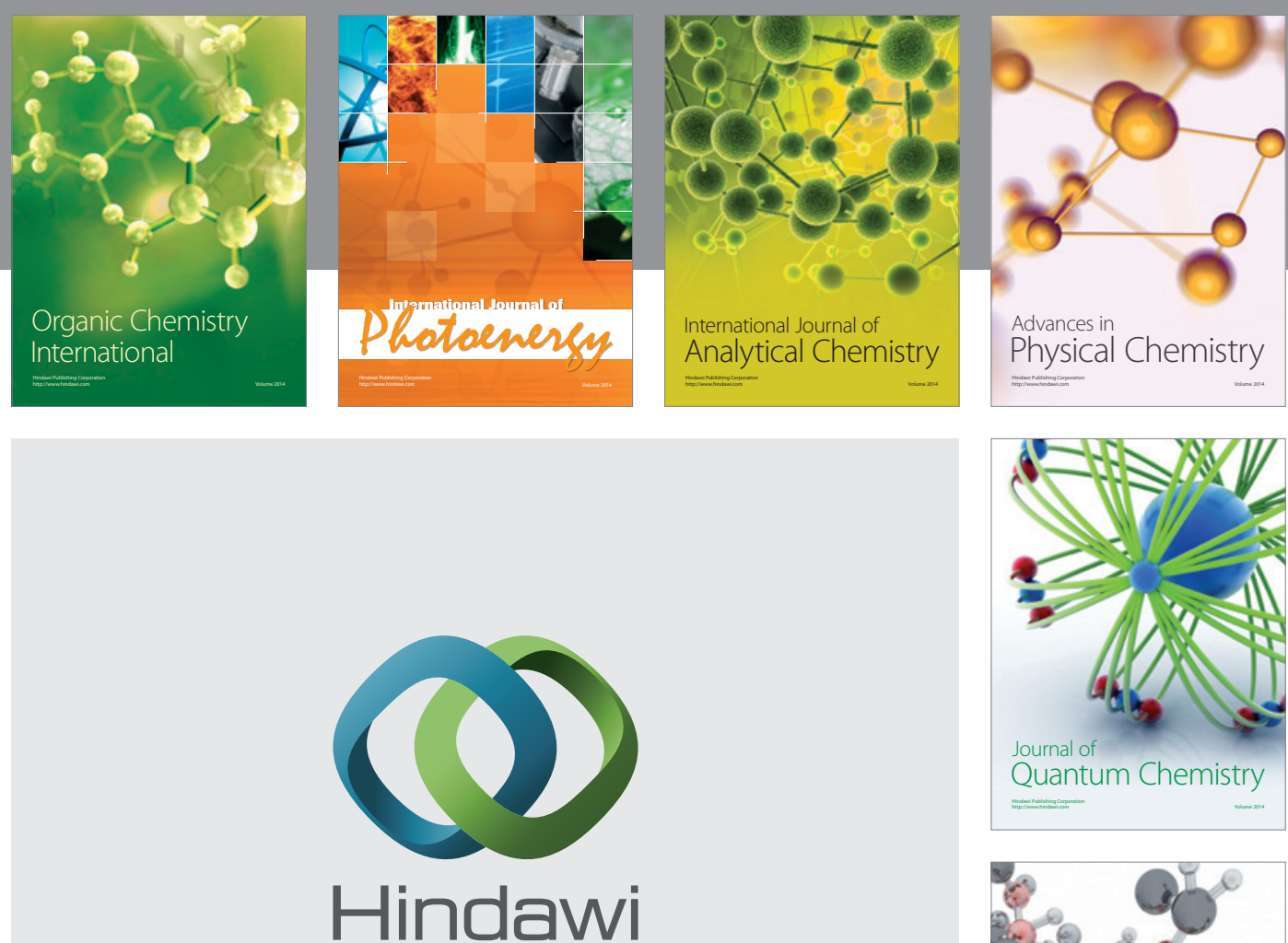

Submit your manuscripts at

http://www.hindawi.com

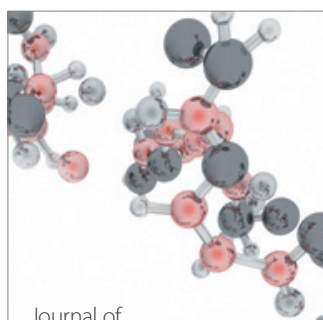

Analytical Methods

in Chemistry

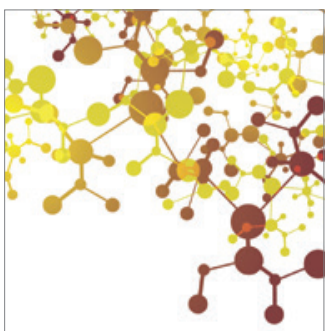

Journal of

Applied Chemistry

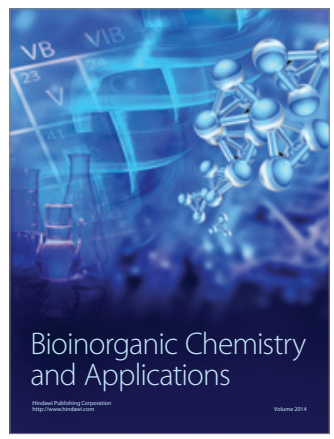

Inorganic Chemistry
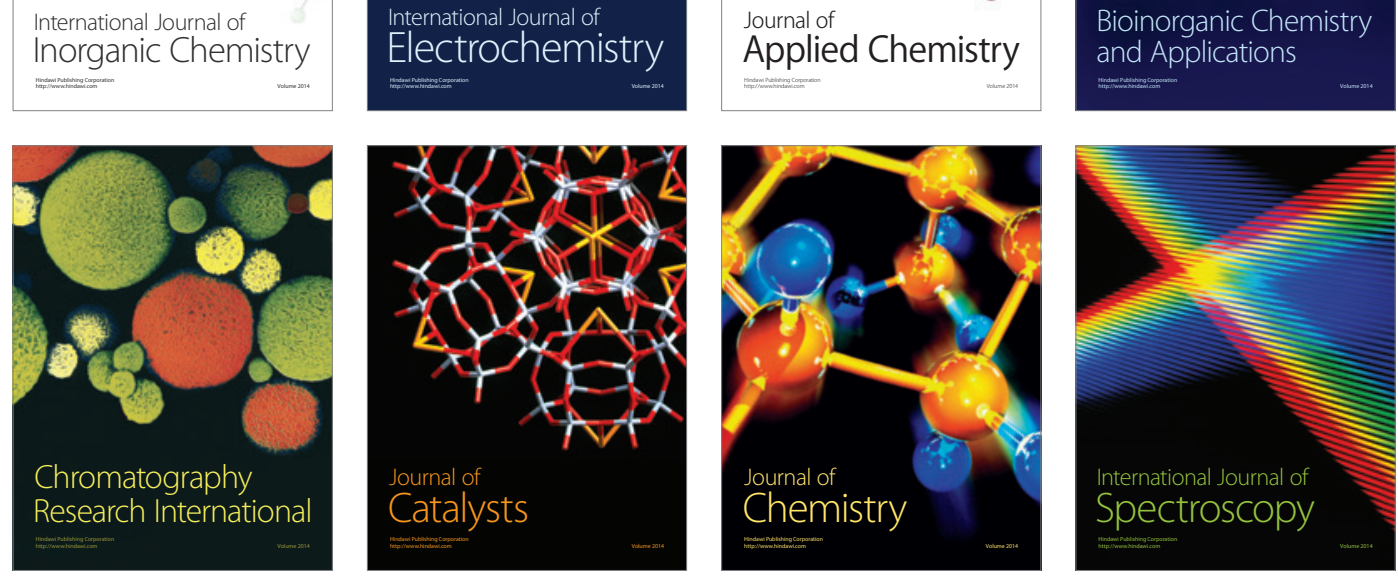